\title{
Eros, Beauty, and Ugliness
}

\author{
Ken-ichi Sasaki
}

I have been given the chance to write on Eros and Beauty, to which I have added "Ugliness". The addition was inspired by the profound ambiguity pertaining to this problem: both Beauty and Eros belong to the intermediate being that is man, who is both body and mind, and from this combination numerous ambiguities are generated. Within this horizon, it would be difficult to talk about beauty without also taking ugliness into account.

At first, I was inclined to reflect on phenomena rather than principles, that is to say "Eroticism and Beauty", rather than "Eros and Beauty". The given theme, however, is evidently Platonic. Without the argument developed in the Symposium, the subject "eros and beauty" would sound dubious. Therefore, we must begin with a brief recapitulation of the views presented in this dialogue.

\section{The Ambiguity of Eros in Plato}

The Symposium is set at a feast celebrating Agathon's recent victory in a tragedy competition. In accordance with the proposal of a guest, each guest delivers a panegyric on the god Eros. Among the six speeches reported in the dialogue, those of Aristophanes, the great comic poet, and of Socrates are most often referred to and discussed. It is these speeches I wish to consider here.

According to Aristophanes, human beings were formerly divided into three species: in addition to man and woman, there existed a third, "hermaphrodite", species, half male and half female. This hermaphrodite was not only strong and energetic, but also arrogant and defiant toward the gods. Being troubled by the human race, Zeus finally found a remedy in cutting them all in half, so that they should be weakened without being killed. As a result, each half body was left with a desperate yearning (pathos) for its missing half; the halves of the former hermaphrodite sex were implanted with heterosexual love (erôs), and those of the former male or female with homosexual love. ${ }^{1}$ 
This mythical account by Aristophanes explains only the origin of sexual desire. It is noteworthy that Freud, borrowing this myth, presents the following hypothetical principle: "when living matter became living matter it was sundered into tiny particles that ever since have endeavored by means of the sexual drives to become reunited". ${ }^{2}$ In Freud's later work, the notion of eros, while still based on sexual desire, is enlarged to include the general principle of inclinations peculiar to life. He explains this as follows: "with ... our extension of the libido concept to the individual cell, the sexual drive transformed itself in our scheme of things into Eros, the force that seeks to push the various parts of living matter into direct association with each other and then keep them together". ${ }^{3}$

With regard to the notion of eros, I am sympathetic to this ambiguous concept of life as equivalent to sex. As he changed the term from libido to eros, Freud must have differentiated these two aspects. However, in attributing the endeavor to be reunited to "sexual drives", he founded life upon sex. Like many people, I can hardly believe in the view that all human living activities are motivated by such drives, though it is undeniable that life is deeply connected with them. In consequence, we can probably accept that even human activities that do not directly express sexual desire nevertheless contain a tint of the sexual, like an echo or a reflection. I feel, for example, from time to time a certain sexiness in artistic expression, especially where it praises vital power that is not explicitly erotic. I especially wish to elucidate here the ambiguity of eros and beauty, which is connected to the Freudian ambiguity of life and sex.

We will now move on to the speech by Socrates, which is presented as the lesson he received from "a Mantinean woman called Diotima". ${ }^{4}$ Here it is Plato himself who interprets ambiguously the meaning of Eros (though differently, of course, than Freud). The starting point is the utterance of Socrates: "Love (erôs) is a great god, and he is the love of what is beautiful". ${ }^{5}$ Diotima, while admitting the second half of this sentence, denies the first half because, she says, Love longs for something beautiful because he lacks it, and therefore he is neither beautiful himself nor a god, but rather a "spirit" (daimôn). A spirit is "halfway between god and man", ${ }^{6}$ an intermediary between them. This means that the love of, or desire for, the beautiful that arises in the human mind is ordained by the gods.

What, then, is the function of Love? In other words, what kind of act can be worthy of the name of love? "To love is to bring forth upon the beautiful, both in body and in soul. ... [When] we reach a certain age our nature urges us to procreation. Nor can we be quickened by ugliness, but only by the beautiful". ${ }^{7}$ Then we look fervently for the beautiful. To begin 
with, we orient ourselves to a "beautiful body", where we produce "beautiful discourse". ${ }^{8}$ But this is only the initiation from which the act of love develops an ever-ascending movement: "from one to two, and from two to every lovely body, from bodily beauty to the beauty of institutions, from institutions to learning, and from learning in general to the special lore that pertains to nothing but the beautiful itself - until at last he comes to know what beauty is". ${ }^{9}$

Octavio Paz says that this sounds like the standpoint of Don Juan and wonders why the personality of the love partner is ignored. ${ }^{10}$ I wonder too. We should however regard this as a criticism unrelated to the standpoint of Plato. Our philosopher considers "procreation", i.e. productivity or creativity, as an act essential to human life ("daimôn" means that), and calls it "erôs" (love). Pregnancy is talked about, but immediately becomes a metaphor for spiritual or intellectual pregnancy, thereby emptying out the erotic content. Referring to Aristophanes' view of eros as consisting in the search for a lost half, Diotima says that "Love never longs for either the half or the whole of anything except the good". ${ }^{11}$ The argument, emptying out the erotic and leading the theory of eros to the intellectual dimension, is most eloquently expressed in the following sentence: "Wisdom (sophia) is concerned with the loveliest of things (kallistôn=the most beautiful), and Love is the love of what is lovely (kalon=beautiful)". ${ }^{12}$

We are recalled to the theory of Ideas in Phaedrus, especially the privileged position of the Idea of beauty. Because of its brilliant character, beauty gives a glimpse of the heavens where we lived in our former life, or of the existence of the Ideas. The Socratic statement at the beginning - that "eros is the love of what is beautiful" - was already thoughtfully arranged in spite of its appearance of being a matter of course. Observed in phenomena in relation to eros, beauty serves only as occasional cause for creative activity, i.e. eros: "procreation upon the beautiful". But the opening sentence of Socrates: "eros is the love of what is beautiful" determines beauty as the final cause of eros. There exists a subtle but decisive shift or extension. If beauty is only an occasional cause, anything can be the object of erotic creation. If, however, beauty is its final cause too, eros not only starts with beauty but must also aim at beauty. Evidently, without putting beauty in the position of object, it would be impossible to argue that intellectual research or creation ends in the intuition of an Idea.

Probably, this view was related, in Plato, to the theory of the chain of beauty developed in Chapter 7 of Ion: stimulated by the beautiful, we try to produce something beautiful. ${ }^{13}$ The motive is eros. Here, unexpectedly, we discover a similarity between Socrates=Plato and Freud. Both posit, 
on the basis of vital activities of human beings, eros as the principle of creativity. With regard to creativity, while Freud only talks about the union and integration of living matter, Plato discerns in it an orientation to beauty. If we limit ourselves to the notion of physical integration, it will be hard to explain cultural activities. Interpreting eros=integration metaphorically and expanding its field of application, we are reaching at a perception of the link between cultural creation and the philosophy of beauty. Human creation can be considered as the realization of a new union or integration in nature and society. It would not be difficult to see that such creation aims at beauty, because the harmony implied in the union corresponds to beauty. Viewed in such a general scheme, we can understand the link between beauty and eros, since they have a feeling of life as their common denominator. Can this ontological theory of eros be backed up by our experiences concerning the erotic? We must examine this question.

\section{The Sexualizing Gaze}

Let us see if this theory can be verified "from below". For while "eros" is the principle of vital working, eroticism designates the erotic as experienced. I wish to begin with an example to be taken as typically erotic in order to theorize from it. However, when we consider any concrete example, the sexual standpoint of the author affects the choice of that example. I am reflecting and writing from the viewpoint of a male heterosexual. If the author was female, she might take something different as erotic, and a homosexual author would show a still different sensibility and judgment. We are not even sure if it is possible to generalize. This limit presupposed, I quote a passage that I find erotic from a novel of Tanizaki:

One summer evening during the fourth year of his search Seikichi happened to be passing the Hirasei Restaurant in the Fukagawas district of Edo, not far from his own house, when he noticed a woman's bare milk white foot peeping out beneath the curtains of a departing palanquin. To his sharp eye, a human foot was as expressive as a face. This one was sheer perfection. Exquisitely chiseled toes, nails like the iridescent shells along the shore at Enoshima, a pearl-like rounded heel, skin so lustrous that it seemed bathed in the limpid waters of a mountain spring - this, indeed, was a foot to be nourished by men's blood, a foot to trample on their bodies. Surely this was the foot of the unique woman who had so long eluded him. ${ }^{14}$

The situation is as follows. Seikichi is a tattooer, formerly an ukiyoe painter. He has "cherished the desire to create a masterpiece on the skin of a beau- 
tiful woman". ${ }^{15}$ Vainly pursuing the woman whose beautiful foot he has noticed, a year passes and his "long-held desire [turns] into passionate love". ${ }^{16}$ The following spring, he receives a visit from a young girl, whom a geisha from Tatsumi has sent on an errand. He intuits that this is the girl... But the story does not concern us; our subject is the above quoted scene.

Nobody would deny that this female foot peeping out from beneath the curtain of a palanquin is described as erotic. Many people, when considering the female body, would certainly not be particularly sexually attracted to the foot. Seikichi does not intend to tattoo the foot. He probably does not deduce the quality of the woman's skin from her foot either. He perceives the woman's foot metonymically, as what "tramples on men's bodies". That must be the "expression" he intuited. He "concealed a secret pleasure, and a secret desire". ${ }^{17}$ The "pleasure" concerns the sadistic one he gets from the torment of those tattooed by him. Yet this "desire" conceals his masochism à la Pygmalion, his "falling captive to the beauty of a woman into which he has put everything, and prostrating himself before her". At the end of the story, the accomplished "desire" overwhelms the sadistic "pleasure".

This sadistic inclination makes him sensitive to the woman's foot, an object that might lack any sexual charge for other people. The above quotation describes not the objective facts, but the gaze of Seikichi. The sexual object does not exist; it is the gaze colored by a particular interest that invests objects with erotic meaning. What is called the indecent gaze is the plain and impudent mode of such gaze. Seikichi's "sharp eye" is no different from the indecent eye with respect to the mechanism of transforming objects into erotic objects. Most women avoid it because of its violent assessment of meaning. Eroticism consists however in this gaze assigning a meaning. Octavio Paz precisely grasps this essence. He says that eroticism "essentially consists of turning aside or changing the reproductive sexual impulse into a representation". ${ }^{18}$

Eroticism is, above all else, exclusively human; it is sexuality socialized and transfigured by the imagination and the will of human beings. The first thing that distinguishes eroticism from sexuality is the infinite variety of forms in which it manifests itself. Eroticism is invention, constant variation; sex is always the same. ${ }^{19}$

Paz's view offers a thorough explanation of the paragraph from "The Tattooer" presented above as exemplary of eroticism. We have recognized there the intervention of the gaze, which transforms the woman's foot from a neutral physical body part and into an erotic object. The gaze 
denatures or more exactly "derealizes" objects and converts them into representations, so as to transform them into the erotic.

Someone might certainly object that there are parts of the body that are erotic even prior to any such gaze: the genitals, the bust, and the hips. We might also wonder if it is possible for every part of the body to be sexualized by the gaze. The first objection is based on realism, and the second, focusing on the reach of sexualization, insinuates a realism too.

With regard to realism, we may consult George Bataille. He shares the view of Paz that eroticism is a human affair. But, while affirming that "essentially, eroticism is the sexual activity of man, as opposed to that of animals", ${ }^{20}$ Bataille is a realist who aims at explaining these sexual activities in terms of physical and mental mechanisms. He even opposes himself to Paz' viewpoint of consciousness. Though admitting that "a naked woman, young and pretty" constitutes "the exemplary form" of the erotic object, Bataille specifies that "a naked woman does not always have the erotic meaning that I ascribe to her. [...] A naked woman if she's old and ugly, leaves most men unmoved; but if such a woman is obscene without disturbing anyone, the obscenity which the nude body of a pretty woman lets one glimpse arouses to the extent that it is obscene, that it causes anguish but does not suffocate, that its animality is repugnant yet does not exceed the limits of horror which beauty makes bearable and fascinating at once"21: the naked body "slips" to the erotic object.

"Animality" and ugliness lie at the core of Bataille's speculation; so he brings forth his "old and ugly naked woman". We perceive the same stance in the phrase: "in front of the shameful nakedness, make the shame and desire a single, violent convulsion". ${ }^{22}$ His description of the sex organ is almost violent. The sex organ's function consists in the conservation of the race's life beyond the "disintegration of the flesh" in death. "Yet, the look of the naked exposed inner mucosae makes one think of wounds about to suppurate, which manifest the connection between the life of the body and the destruction of corpus". ${ }^{23}$ If one starts out from physical ugliness, equally physical beauty should be an indispensable condition for the "slipping". "The formation of eroticism implies", he says, "an alteration of repulsion and attraction". ${ }^{24}$ However, Bataille's solution - that the obscene becomes erotic when it is also beautiful - appears to me, even admitting that there are such extreme cases, a little bit strange.

First of all, for a foot fetishist like Seikichi, a "beautiful" foot is surely erotic, but a non-beautiful foot simply lacks charm, and he does not, I believe, discern a "repugnant animality" in it. In its natural state, a foot has no sexual meaning at all. I find here a problem for the Bataillean concep- 
tion of the slide from the obscene. In his notion, the "obscene" designates the animalistic sexuality of such parts, and it is ugly because it connotes animality. But an "old and ugly naked woman" not only "leaves most men unmoved", but fundamentally is not obscene. The argument of Bataille is realistic. In the system of nature, there are obscene parts destined for sex (the sex organs in the first place, and then the naked body as their extension), which are necessarily ugly because they are real and consequently animal. Therefore it becomes necessary to have something that causes them to slide towards the erotic object, and such a function is charged to beauty. Starting from one scene in "The Tattooer", we have recognized there a function of representation executed under a certain interest. In our opinion, the "slip" is nothing but this representation. Bataille, on the contrary, wishes to exclude, as much as possible, all subjective moments such as sexual interest. His conception of ugliness neutralized by beauty reflects such a realistic attitude. I say "as much as possible", because we notice here and there subjective moments. When he says, for example, "most men", it reveals that he acknowledges that there is a minority interested in what most are not, and that it is impossible to explain the "slip" in these men's case without taking into account their "taste" or interest. The limit of Bataille's argument lies in his trying to reduce the phenomenon of the consciousness that is sexualization to a realistic mechanism of the body.

Certainly, taking the minority, as exemplified by Seikichi, as a model case, the consciousness of representation seems to be decisive. We can even imagine that the framing of an object under such a peculiar sexual interest makes this object erotic. Among the various programs of this framing, the one so strong that it becomes exclusive and abnormal is called fetishism. It is however undeniable that there exist for "most men" particularly erotic parts such as bust, hips and legs: the parts favored in pin-ups. The privileged character of these parts is probably based on nature, but they are not always determined as sexual. Being culturally reproduced through image and language, they have become now so ambiguous that we cannot tell whether they are natural or cultural: hence, Paz can talk of cultural creation. But this tendency remains a standard to which fetishism is contrasted as singular.

The existence of "erotic parts" is related to the mechanism of representation too: it is natural that erotic representation, as framing, focuses on bodily parts rather than the body's totality. The personality of the woman disappears and the framed and sexualized part comes to the fore. I will now quote a part of a novel by Junnosuke Yoshiyuki. It is a description of a man who molests a woman he meets on a train. 
It was not so crowded on the train. Imura was standing by the door. Beside him stood a woman - apparently married - of about twenty-seven or twenty-eight. He recalled Kogure's funeral, and then Kyoko Kogure. Memories of young days flitted through his mind, leaving a faint volatile scent in the depth of his nose.

From that moment on, he became increasingly aware of the presence of the woman beside him. He sensed her as a series of segments; the flesh feeling of shoulder when she moved her arms, the arch of her bust, the curve suddenly swelling out from the waist to the haunches, the volume of hips. The vivid illusion of these accumulated parts absorbed and oppressed him. ${ }^{25}$

For Imura, Kyoko Kogure was an idol during his youth. That consciousness of "woman" finds its object in the woman at his side. "The flesh feeling of shoulder when she moves her arms" is sexualized by his sexual consciousness. At the same time, we should take into account the fact that the above quoted passage describes the parts as already sexualized. Before receiving his gaze, her shoulder had been just a shoulder without any sexual meaning. Admittedly, "the arch line of the bust", "swell of the haunches", and "the volume of hips" all describe the parts ordinarily taken for erotic in themselves. But they had to be cut out and framed in order to become representation. The passage by Yoshiyuki is a description of the "vivid illusions" of Imura, and the "illusion" is nothing but a product of the representation that sexualizes the body. In the case of human beings, who unlike animals have no mating season, eros is differentiated from work and life. We quite often hear the story of a man and a woman who have long been in an ordinary relationship, and suddenly fall in love. At that time, this border was crossed. The limit of representation probably coincides with that of the variety of fetishisms.

In short, eroticism can be called a problem of meaning, providing that we understand that it concerns interpretation as well as the signification transmitted from the object, or more exactly, giving meaning rather than interpretation. In the manner of Stendhal, we should talk about the crystallization of eroticism. Eros as life $=$ sex is condensed to a small part, and consequently that part appears as erotic.

\section{Pragmatics of Eroticism}

To sexualize is to place a female body within a sexual horizon. The width of this horizon varies. Imura, seeing complicity in the reaction of the woman, pushes his luck, pursues her when she gets off the train, and is arrested for "attempted rape". There was an exchange of two wills, and what I mean here by "pragmatics" is the dimension of such will. Even when a 
girl is watched from afar, if a definite male will intervenes, sexualization is carried out. In such a monologue-like situation, pragmatics is still at work. For example, from the assumption that "from this distance, I may enjoy parts of that girl as sexual representations" as practical code, sexual representation proceeds.

The will of sexualization does not necessarily aim at intercourse. Such will, exceeding the stage of representation, is exceptional for eroticism. Paz designates the purification to love. We cannot tell what Imura aimed at when he pursued the woman. He probably cannot tell either. The only certain thing is his intense sexual interest. But does the love of very young boys and girls, who lack the notion of sex, belong to eroticism? Even if they do not know what they wish to do, if they feel, in the presence of a particular girl/boy, an exaltation of heart that they have never experienced with a friend of the same sex, this must be a more or less a sexual consciousness. We hesitate to talk about eroticism in such cases, probably because the representation is still raw, even though fervent. Parallel to this, in the case of an impotent old man, eroticism can be deeper, because his sexual interest concentrates on representation. Tanizaki's "mad old man", who seems to be about 80 years of age, says as follows:

I haven't the slightest desire to cling to life, yet as long as I live I cannot help feeling attracted to the opposite sex. I am sure I'll be like this until the moment of my death. I don't have the vigor of a man like Kuhara Fusanosuke who managed to father a child at ninety, I'm already completely impotent. Even so, I can enjoy sexual stimulation in all kinds of distorted, indirect ways. At present I am living for that pleasure, and for the pleasure of eating. ${ }^{26}$

What is this "sexual stimulation in all kinds of distorted, indirect ways"? He is conscious of his own ugliness:

Not even monkeys have such hideous faces. How could anyone with a face like this ever hope to appeal to a woman? Still, there is a certain advantage in the fact that it puts people off guard, convinces them that you are an old man who knows he can't claim that sort of favor. But although I am neither entitled nor able to exploit my advantage, I can be near a beautiful woman without arousing suspicion. And to make up for my own inability, I can get her involved with a handsome man, plunge the whole household into turmoil, and take pleasure in that. ${ }^{27}$

Taking advantage of his ugliness and old age, he looks for possible forms of "sexual stimulation". The main partner of his sexual life is Satsuko, the wife of his son, who lives in the same house (or mansion) with him. Her dancer's figure perfectly suits his taste. Her sexual self-confidence is ex- 
pressed unconsciously in a sadistic manner, which harmonizes with the masochism of the old man, intensified by his lost "ability". Satsuko knows the old man's "pleasure" and interest in her, and profits from it when he gives her expensive presents. In return for these, she for example one day invites him to the shower room and shows him "a leg ... between the curtains", which she allows him to kiss.

I crouched over just as I had on the twenty-eighth of July, glued my lips to the same place on her calf, and slowly savored her flesh with my tongue. It tasted like a real kiss. My mouth kept slipping lower and lower, down toward her heel. To my surprise, she didn't say a word. She let me do as I pleased. My tongue came to her instep, then to the tip of her big toe. Kneeling, I crammed her first three toes into my mouth. I pressed my lips to the wet sole of her foot, a foot that seemed as alluringly expressive as a face. ${ }^{28}$

Such physical contact, while only "nothing above the knee" for Satsuko, is for the old man a compensation for the intercourse that is impossible - even two or three hours later, he shows an extraordinary hypertension, panicking the resident nurse. He also tries to incite Satsuko to deepen her relationship with Haruhisa, his nephew, who is interested in her: to "plunge the whole household into turmoil". To sum up, his sexual pleasure in "distorted, indirect ways" ranges from proximity to a beautiful woman, through petting, to observation of the sexual adventures of others. While being with a beautiful woman and physical contact are parts of a normal sexuality, his taste for turmoil appears to be abnormal. But as far as it concerns the enjoyment of observing the sexual acts of others, this belongs to the same category as peeping, which is probably more repulsive.

The sexualizing consciousness shows great variety in its objects. In every case, mutual communication intervenes. In the case of looking at a pinup with sexual interest, the wills of the publisher and consumer are so evident that we hardly notice this communication. But in most cases of sexual representation, this communicative layer exists as a basis. Imura on the train, making a slight pass, finds that the woman reacts as an accomplice and then proceeds to the next step. When he misreads her will, he is prosecuted as a criminal.

The first chance for the "mad old man" appears to be presented by Satsuko. "Now and then, between the shower curtains, she let me see a flicker of a shoulder, a knee, the tip of a foot." ${ }^{\prime 2}$ These parts are framed by the curtains, and therefore already erotic. One day, his wish to be permitted to rub her back with a towel after her shower is fulfilled. Then, the old man "grasped her shoulders" to give "her a tongue-kiss on the soft curve of her 
neck at the right shoulder". Immediately, he "got a stinging slap" on his cheek - which must be a pleasure for him! He said, "I thought you'd allow that much" ${ }^{30}$ Sexualization proceeds step by step, constantly verifying the will of the partner.

There are what can be called expressions of the will to sexualization. It is uncertain whether they have codes or not. Direct expression, shortcutting the representation (mostly by men), is too obvious and made fun of for that, or detested for lack of delicacy. If one does not notice the intention of a delicate expression (this too seems to be a male characteristic), one is blamed for dullness. The meaning of what appears to be the same expression can have changed between a little while ago and now. The reason why many sex criminals, including Imura, claim the agreement of the other party may lie in this ambiguity of the code.

This expression of will works not only between lovers or those in similar personal relationships, but also in impersonal and public contexts. Particular clothing, make-up, actions, or gestures can express to unspecified people a will for sexualization. An extreme miniskirt, a low-necked blouse, pants clearly showing the hip line, heavy make-up, impractical hair-design, actions such as "Monroe walking", among others, are generally (to the utmost generally) to be glossed as signifying the wish to be regarded as erotic representation. Coquetry and flirtation between individuals and such signals in public space are perceived as "sexy": among sexual phenomena, what is already represented is called sexy. By contrast, there also exist expressions of the refusal to be sexually represented. These could be the childish and the intellectual. As there is, however, a minority who wish to regard just these as particularly erotic, it is impossible to codify the matter.

The basic ambiguity in pragmatics consists in how to deal with the partner's will. To simplify, it concerns the two attitudes: respect or neglect. This means that the problem of personality is involved in eroticism. As mentioned above, Octavio Paz thinks that the sexual behavior of animals becomes eroticism through representation, which is still further refined to become love: what mediates eroticism to love is personality. What differentiates love (more precisely sexual love) from "love" of one's country or of ideas is "the erotic element", that is to say "the attraction to a body". ${ }^{31}$ Love is determined by three features: "exclusivity, which is love for only one person; attraction, which is one's fate freely accepted; the person, who is a soul and a body". ${ }^{32}$ Representation on the basis of normal human relations, and especially where destined to become refined love, proceeds by means of communication between wills. 
The sexual representation that neglects the will and the personality of the partner produces an eroticism not linked to love. Paz mentions this as the root of a contemporary disease; "the expropriation of eroticism and love by the power of money" and "the vanishing of the person". ${ }^{33}$ The commercialization of eroticism develops, shortcutting the communication of will, outside of personality.

Between two individuals who meet in passing, only gazes are exchanged without a personal link. I have mentioned the violence of such a gaze, which represents the other's figure sexually without regard to his/her will. A woman, exposed to such a gaze, will reject it as "repulsive". Such a thing does not happen between lovers who are in a personal relationship, and decide everything respecting mutual will. However, such communication of will is not univocal, and there always remains room for diplomacy. This dynamic is omnipresent in personal commerce, because no one always has a firm will; everyone is unsure at times. Even in the case of Imura's molestation, he tried to gauge the woman's will to a certain extent.

Sadism and masochism are essentially a matter of the pragmatics of personal relationships since the essence of their pleasure consists in the treatment of the partner's will. A sadist finds his/her pleasure in forcing the partner beyond his/her will, and a masochist in having his/her will overruled. These are evidently forms of personal relationship; if there is no fundamental underlying agreement, the act of a sadist would purely and simply be a crime. In the usual case of personal relationships, on the other hand, if a dynamic exchange of wills works, there should exist a rather aggressive part and a rather passive part. Then the former is more or less sadistic, in so far as he is happy with his part, and the latter masochistic. In the final analysis, these forms of sexual consciousness, which are considered as abnormal, belong to the basic elements of human relations.

\section{Eroticism/Eros and Beauty}

We have been examining the sexualizing consciousness and its pragmatic dimension with regard to eroticism as representation. We shall now consider the relationship between eroticism and beauty. Here the main subject should be the body or flesh as living body. In this development, the theme should return from eroticism as consciousness to eros as reality. The body in eroticism is one that is watched under the consciousness of sexualization. In that case, beauty is probably equivalent to the erotic: the erotic is beautiful. But is it valid to say the reverse: that the beautiful is erotic? 
According to Plato, the answer is yes: it must be eros as harmonizing creative power that produces beauty. It is just here that a Platonic paradox appears. While eros is incorporated into the body as an instinctive tendency, eros tends at the same time to transcend the body in its orientation to the Idea: "from one to two lovely bodies ... to learning of the beautiful itself." However, is the Idea really beautiful and bright? Ideas are prototypes, in the ideal world, of material objects and human behaviors on earth. They plainly lack or are exempted from the "flesh" peculiar to terrestrial individuals. Can such things be beautiful? Staying on the level of the flesh, the beautiful can be erotic. But Valéry, for example, doubts the ideality of beauty.

The dialogue Eupalinos, with an epigraph "for grace", develops between Socrates and Phaedrus in the land of the dead. The work is well known as a theory on architecture with a philosophical application to the problem of creation in general. The particular setting for this theme contains a bitter irony. ${ }^{34}$ The country of pure souls is far from being one of clear insight; rather it is dully stale. Two characters, having become shadow-like ghosts and "light", discuss architecture, the most material art, and beauty, which they can no longer feel: they have to talk about them as memories. Phaedrus recalls Eupalinos from Megara. The small chapel dedicated to Hermes, which was constructed by this eminent architect, had an "inexplicable grace" because it was the "mathematical image of a young girl from Corinth" whom the architect had loved, which brought about the feeling of "the flower of young womanhood". ${ }^{35}$ Let us consider the case of a young, beautiful woman, who died a sudden death, such as Eurydice. The proportions of the details of her face and body stay the same. If proportion determines beauty, if, in other words, beauty is a static figure, she must be said to be beautiful even now. But there is something definitively lost with death: the vital charm that is grace. The irony of Valéry finds its most relentless expression in this word, "grace".

Grace as beauty full of life is the "girdle of Aphrodite". Wishing to beguile her husband Zeus, Hera polishes her skin, perfumes her whole body, puts on a special embroidered robe, fastens the front with a golden brooch, and puts on earrings, so that "abundant grace shone therefrom". Unsatisfied, however, with this, the goddess calls Aphrodite, the goddess of beauty, and requests "love and desire". In compliance with this, Aphrodite gives Hera "the broidered zone, curiously-wrought, wherein are fashioned all manner of allurements; therein is love, therein desire, therein dalliance beguilement that steals the wits even of the wise" ${ }^{\prime 36}$ : in short, glamour or sexiness. Indeed, at a glance, Zeus falls in love with his old wife wearing 
this zone. Referring to "Aphrodite's zone/girdle" at the beginning of his treatise On Grace and Dignity, Schiller identifies it with grace. As is suggested by the above presented episode, "grace is not the exclusive privilege of the beautiful; it can also be handed over, but only by beauty, to an object less beautiful, or even to an object deprived of beauty". ${ }^{37}$ Although Schiller deduces from this the modern determination that grace is beauty of movement, judging from Homer's episode it would be more natural to think that grace is glamour or sexiness.

The erotic is combined in the first place with the beautiful, but can be bestowed on the non beautiful, or even the ugly, and in such cases, gives the ugly a reflection of beauty. We can verify this ambivalence in Tanizaki, Bataille and Paz. Tanizaki's "mad old man" is conscious of the "masochistic tendency" in himself that makes him "more attracted, more fascinated by women who cause him [me] pain". That is the erotic he feels, i.e. his "grace" or glamour. At the same time, however, he needs a beauty "pleasing to his [my] aesthetic tastes". ${ }^{38}$ As mentioned before, in Bataille the beauty of the woman constitutes the necessary condition for animality to be counteracted and the erotic to appear. Both focus on the overlapping case of beauty and grace. Paz, by contrast, considers that "it is plural and mutable. There are as many ideas of physical beauty as there are civilizations and eras", and affirms that "beauty plays only a minor role in amorous attraction" ${ }^{39}$ This means that he pays more attention to the case where grace is combined with things other than beauty. We can however say that he contradicts himself, because, supposing that beauty is subjective, when someone is "attracted", the charm he feels can be judged as the charm of beauty: "the erotic is beautiful". If so, then everything in the territory of eros should be beautiful and there will be no room for ugliness. But we should be careful not to reduce all to subjectivity. We must found eroticism as representation upon eros as reality. We have criticized Bataille above for trying to give a realistic explication of eroticism, which is representation. But at the level of eros as reality, his intuition about the "sex organ as wound" might contain something essential. Indeed everyone realizes at times that eros is not only charming but also disturbing: that it is already near to ugliness.

\section{Real Eros and Beauty}

Let me describe a skit performed by a comic duo, which I designate $A$ and $B$. $B$ plays the part of a girl, sitting on a chair facing away from the audience. Attracted by her back view, $A$ addresses her. A chat ensues, as between a new young couple. They seem to get along with one another. 
$A$ is excited with the expectation of new love. Then $B$ turns to him, and her face is made up to appear extremely ugly. $A$, after being momentarily stunned and stupefied, makes a violent gesture of vomiting.

The point is the reaction of $A$. Why does he wish to vomit? It is as though he wishes to spew out something from the inside of his body. What does he so strongly wish to discharge? He wishes to deny his sexual interest in this ugly girl before him, and to expel from his heart the rest of such a sentiment. It is shameful to feel even a slight desire for someone whom one would never take for such an object, and such a mean desire testifies to an inner impurity, which provokes physiological disgust. This is what the intensity of his reaction means.

Is the desire itself ugly? If the targeted girl had been beautiful, he would not have vomited; therefore we cannot conclude that the desire is ugly. ${ }^{40}$ We should rather consider as follows. The ugliness of the girl suspends the desire, and the desire is now regarded objectively, so as to appear ugly. This dynamic is common to all phenomena of life. Every working of life changes to something impure, unclean, or stained when it is detached from its original place and objectified. Typical in this respect is bodily waste. It is a remarkable fact that when inside the body, it has not been disgusting, and the body has not been disgusted by it, but once excreted, it suddenly transforms into something extremely repulsive. All bodily waste does so, but bodily fluids in particular. A moment ago, it was mine and probably clean from the viewpoint of hygiene, but once spit out, saliva is so disagreeable that we wish to avoid touching it. Such transubstantiation is not limited to the body. I feel a certain physiological aversion to the leavings on someone else's plate. The feeling of hatred one has for a desire conceived for something ugly seems to be of the same nature.

This experience of ugliness cannot be interpreted in a solipsistic way. The "mad old man" coaxes Satsuko to give him a deep kiss, like a spoiled child, on the pretext of a sudden pain in his fingers. In the end, "she finally got way without kissing me. She wouldn't let our mouths quite touch they were only a centimeter apart, and she had me open mine wide, but all she did was let a drop of saliva fall into it". ${ }^{41}$ The astonishing pleasure he gets from this reminds us of the pragmatic dimension. Even our own saliva, definitively spit out, causes a sense of filth. Yet, because it is of the woman one wishes to be united with (that is to say the "beautiful" woman), it can be a source of pleasure. A piece of steak left on the plate of a loved one or a family member is not a filthy leftover. If I still have some appetite, I will willingly eat it. Judging from this, life as eros seems to have a certain sphere, let us say the sphere open to union, because eros is 
the power that unifies. Expelled from that sphere, things concerning life (especially sex) become repulsive and filthy.

Henri Gouhier believes that every real thing is beautiful: that the ugly is not the opposite of the beautiful. Ugliness is a particular phenomenon that appears when something pretending to be beautiful fails to fulfill that promise. ${ }^{42}$ In the sense that it presupposes human will, ugliness is a purely human phenomenon. Applied to the problem of eros, this notion seems to coincide with our consideration above, because eros, although presupposing no will, is dominated by the orientation to beauty. When phenomena betray this orientation, ugliness appears. In other words, eros = life glows with beauty when its unifying nature is freely displayed, but when it fails to do so and becomes objectively regarded, a shadow of ugliness is cast. Life is probably ambiguous, i.e. at the same time beautiful and ugly. It is probably for that reason that we feel somewhat ashamed at the failure in the project, and the breakdown of the will. Ugliness is connected to the sorrows of life.

\section{Notes}

1.Plato, Symposium, $\mathbb{1 4 - 1 5}$. I have consulted the English translation by Michael Joyce, in: The Collected Dialogues of Plato including the Letters, edited by E. Hamilton and H. Cairns, Princeton University Press, 1961. I will quote from this translation. I also consulted: Plato the Symposium, with Introduction, critical notes and commentary by R.G.Bury, Cambridge Heffer and Sons, London, 1909.

2. S. Freud, "Beyond the Pleasure Principle", translated by John Reddick, in: Beyond the Pleasure Principle and Other Writings, Penguin Books, 2003, p. 97.

3.Ibid., p. 252.

4. Plato, Symposium, op.cit., p. 553 (201D). The whole construction of this dialogue is interesting because of its particular structure, which sets the story within several frames. A certain Glaucon, having overheard someone telling Phoenix of the feast, asks Apollodorus to tell him about it. According to Apollodorus, it happened long, long ago, when they were children. He was told about the event by the same person who had been talking to Phoenix: Aristodemus. Apollodorus agrees to tell his friend what Aristodemus told him. His report now includes the discourse by Socrates reporting the lessons given by Diotima. Why did Plato adopt such complicated framing? I need a specialist on Plato to give me an explication of this problem. The effect I feel is that the contents of the talk are rendered apparently mythical.

5. Ibid., p. 554 (201E) - I have changed the tense of the translation.

6.Ibid., p. 555 (202D-E).

7.Ibid., p. $55^{8}$ (206B-C). 
Eros, Beauty, and Ugliness

8. Ibid., p. 561 (210A).

9. Ibid., p. $563(211 \mathrm{C})$.

10. Octavio Paz, The Double Flame, Love and Eroticism, translated from Spanish to English by Helen Lane, a Harvest Book, Harcourt Brace, 1995, pp. 50-52.

11. Plato, op.cit., p. 558 (205E).

12. Ibid., p. 556 (204B).

13. Appealing to the simile of magnetism, Socrates says: the "power [of the magnetized rings] depends upon that loadstone. Just so the Muse. She first makes men inspired, and then through these inspired ones others share in the enthusiasm, and a chain is formed, for the epic poets, all the good ones, have their excellence, not from art, but are inspired, possessed, and thus they utter all these admirable poems". Ion, translated by Lane Cooper, in the same collected volume as the Symposium, p. 220 (533D-E).

14. Junichiro Tanizaki "The Tattooer", in Seven Japanese Tales, translated by Howard Hibbett, third ed., Tokyo, Charles E. Tuttle Co.: Publishers, 1970, p. 163

15. Ibid., p. 162.

16. Ibid., p. 163 .

17. Ibid., pp. 161-2.

18. Octavio Paz, op.cit., p. 128.

19. Ibid., pp. 8-9.

20. George Bataille, The History of Eroticism, volume 2 of The Accursed Share, an Essay on General Economy, translated by Robert Hurley, Zone Book, 1991, p. 27

21. Ibid., p. 147.

22.Ibid., p. 178.

23. Ibid., p. 130.

24. Ibid., p. 48. We should note that Bataille passes here from the objective to consciousness, which however is passive.

25. Junnosuke Yoshiyuki, Plants on Sands, in Complete Works, vol. 6, Tokyo, Kôdansha, 1983, p. 34 (my own translation).

26. Junichiro Tanizaki, Diary of a Mad Old Man, translated by Howard Hibbert, Oxford University Press, 1988, pp.17-18 (June 19).

27. Ibid., p. 18.

28. Ibid., p. 66

29. Ibid., p. 48 .

30. Ibid.

31. O. Paz, op.cit., p. 127.

32.Ibid., p. 159.

33. Ibid., pp. 204-05. The author mentions "the commercialization of art" on p. 247.

34. Phaedrus says: "Nothing beautiful is separable from life, and life is that 
which dies". To this comment, Socrates mumbles: "But most people have of Beauty immortal notion of some kind". Valéry, Eupalinos or the Architect, in Dialogues, translated by William McCausland Stewart, Routledge \& Kegan Paul, 1957, p. 76.

35. Ibid., p. 82.

36. Homer, The Iliad, Ch. 14, translated by A.T. Murray, II, the Loeb Classical Library, Harvard University Press, 1967 (1925), p. 83.

37. Schiller, "On Grace and Dignity", in: Friedrich Schiller's Works, vol. 7, "Aesthetics and Philosophical Essays", London, John C. Nimmo, 1903, p. 168.

38. Tanizaki, Diary of a Mad Old Man, op.cit., p. 26 (July 10).

39. O. Paz, op.cit., p.153.

40. It might at first appear that this is Bataille's schema of neutralization, but it is not the same. While Bataille argues that physical ugliness is neutralized by physical beauty, I here relate psychic desire and physical beauty: this is the Platonic scheme.

41. Tanizaki, Diary of a Mad Old Man, op.cit., pp. 133-34 (October 13).

42. Henri Gouhier, "Introduction à la philoshophie du beau", Revue des Cours et Conférence, 38e année, 1936-37. 